Winter 2009

\title{
An Open Letter from Heaven to Barack Obama
}

F. Michael Higginbotham

University of Baltimore School of Law, higginbotham@ubalt.edu

Follow this and additional works at: http://scholarworks.law.ubalt.edu/all_fac

Part of the Civil Rights and Discrimination Commons, Constitutional Law Commons, and the Supreme Court of the United States Commons

\section{Recommended Citation}

An Open Letter from Heaven to Barack Obama, 32 U. Haw. L. Rev. 1 (2009)

This Article is brought to you for free and open access by the Faculty Scholarship at ScholarWorks@University of Baltimore School of Law. It has been accepted for inclusion in All Faculty Scholarship by an authorized administrator of ScholarWorks@University of Baltimore School of Law. For more information, please contact snolan@ubalt.edu. 


\title{
An Open Letter From Heaven to Barack Obama
}

\author{
F. Michael Higginbotham
}

Since the passing of A. Leon Higginbotham, Jr. in 1998, many have wondered what the award-winning author, longest-serving black federal judge, first black to head a federal regulatory agency, recipient of the Spingarn Medal and the Congressional Medal of Freedom, and author of the famous "Open Letter to Clarence Thomas" would think of the state of race relations today. Appointed to the Federal Trade Commission in 1962, Higginbotham served in several powerful federal positions including Vice-Chairman of the National Commission on the Causes and Prevention of Violence, member of the first wiretap surveillance court, and chiefjudge of a United States Court of Appeals. Known as the conscience of the American judiciary on race issues, Higginbotham caused controversy in 1992, when he publicly reminded Justice Clarence Thomas of his predecessor's contributions to racial equality. In the 18 years since this public letter, much progress has been made, including Higginbotham's former student, Michelle Obama, becoming the first black first lady. This article presents what might have been Higginbotham's letter to President Obama after one year in office.

January $20,2010^{1}$

\section{Dear President Obama:}

I rarely write letters that are published for the public to read. In fact, of the thousands of correspondences penned during my career, only one prior to this

F. Michael Higginbotham, my nephew and protégé, is a professor of law at both the University of Baltimore and New York University. Although I have no brothers or sisters, I always refer to Mike as my nephew even though Mike's dad and I are cousins. In the Higginbotham family, it is customary to refer to children of cousins from the same generation as nephews or nieces, consistent with a tradition followed by some black families with Southern roots. Mike worked closely with me on my two books and on numerous law review articles spanning thirty years. He is the author of the forthcoming book Getting to the Promised Land: How Blacks and Whites Can Create Racial Equality, which provides an in-depth look at racism in America today. His earlier book, RACE LAW: CASES, COMMENTARY, AND QUESTIONS (3d ed. 2010), now in its third edition, is dedicated to me and includes my "open letter" to Associate Justice Clarence Thomas. The author would like to thank Alexis Martin, a 2009 graduate of the New York University School of Law, for research and editorial assistance, and Martha Kahlert and Barbara Coyle for secretarial support.

1 This letter articulates what the author believes Judge A. Leon Higginbotham, Jr., deceased, would have written. See infra note 109. 
has been published. ${ }^{2}$ It was sent to Justice Clarence Thomas eighteen years ago, shortly after his contentious confirmation as the 106th Justice of the United States Supreme Court, and only the Court's second black nominee. My letter generated a good degree of controversy, even though it was not sent from Heaven. ${ }^{3}$ Justice Thomas's nomination was hotly contested. The American Bar Association (ABA) rated him lower than his predecessors; ${ }^{4}$ his lack of judicial experience (Thomas had never written a legal book or significant article and had only been a federal judge for one year) drew sharp criticism from detractors such as the National Association for the Advancement of Colored People (NAACP) and the National Organization for Women (NOW); ${ }^{5}$ and he was confirmed (after overcoming rejection of his nomination by the Senate Judiciary Committee) by the smallest margin of votes (four) of any Supreme Court nominee since Lucius Lamar in $1888 .^{6}$

As the longest-serving black federal judge at that time, I wrote that letter with the hope that reminding Justice Thomas of the great legacy of Justice Thurgood Marshall might encourage him to follow Justice Marshall's admirable path. As the first black to serve on the Supreme Court, Justice Marshall's defense of minorities, the poor, women, the disabled, and the powerless was unsurpassed. While I must confess to having had reservations about making that letter public because it could have been perceived as arrogant or inappropriate judicial conduct, I decided that the potential public good far outweighed any negative consequences that may have accrued to me personally. My apprehensions about Justice Thomas have proved to be wellfounded and my words do not appear to have had much influence. ${ }^{7}$ Yet, I have no regrets about writing or publishing the letter, for I believe it sparked valuable public discourse.

2 A. Leon Higginbotham, Jr., An Open Letter to Justice Clarence Thomas from a Federal Judicial Colleague, 140 U. PA. L. REv. 1005 (1992).

${ }^{3}$ See David Margolick, At the Bar; A Black Jurist, in an Open Letter, Says Justice Thomas Must Not Forget a Debt to the Past, N.Y. Times, Feb. 14, 1992, at D20.

${ }^{4}$ See Bob Dart, Thomas Ends Testimony; Bush Confident; But Lawyers Warn He Lacks Experience, ATLANTA J. \& ConST., Sept. 17, 1991, at E1.

5 ANDREW Peyton Thomas, ClaRENCE THOMAS: A BIOGRAPHy 282, 320, 357-58 (2001).

6 United States Senate, Supreme Court Nominations, present-1798, http://www.senate. gov/pagelayout/reference/nominations/Nominations.htm (last visited Nov. 30, 2009).

7 Frequently taking the point of view that the Fourteenth Amendment does not permit consideration of race, Justice Thomas has taken this country backwards in terms of providing equal opportunities for racial minorities. He voted with the majority in Gratz v. Bollinger, 539 U.S. 244 (2003), to limit the use of race as a factor for college admissions and again in Parents Involved in Community Schools v. Seattle School District No. 1, 551 U.S. 701 (2007), with respect to elementary schools. Justice Thomas even showed his approval if the Court wishes to undo the judicial precedent, championed by Justice Thurgood Marshall, of Brown v. Board of Education, 347 U.S. 483 (1954), by joining Justice Scalia's dissent in Grutter v. Bollinger, 539 U.S. 306 (2003). 
This second "open letter" is spurred by similar and yet different motivations. I was inspired to write both because I recognize the responsibilities and peculiarities unique to a black man in a position of power, having been a black man appointed to many powerful positions in my time. ${ }^{8}$ I am most invigorated when I see another poised to make a real impact on this country I love. I also recognize the need to make changes, not the least of which is eradicating racism that has hindered opportunities for millions of blacks and stunted America for far too long.

Rather than apprehension, however, I feel inspired by your platform and speeches. I regret that our paths did not cross during my lifetime, despite my teaching at your law school alma mater in the 1980s and 1990s. Your name comes up often these days in Heaven, particularly from persons like myself, who were active participants in the civil rights movement. Just yesterday, Rosa Parks ${ }^{9}$ and I discussed how you can ignite monumental change. It is in this spirit that I now write.

${ }^{8}$ My full name is Aloyisus Leon Higginbotham, $\mathrm{Jr}$. The unique spelling of my first name results from how my father's name is spelled on his birth certificate. I was born the only child of Aloyisus Leon Higginbotham, Sr., and Emma Douglas Higginbotham in Trenton, New Jersey. I graduated from Ewing Park High School in Trenton at the age of sixteen, began my college education at Purdue University, and transferred to Antioch College in Ohio, from which I graduated in 1949. I entered law school at Yale University at a time when there were only two other blacks in my class. Through tireless effort, I was able to graduate at the top of my class from Yale Law School in 1952 and was admitted to the Pennsylvania Bar in 1953. In the years following, I served as President of the Philadelphia branch of the NAACP, a commissioner of the Pennsylvania Human Relations Commission, and a special deputy attorney general. In 1962, after a successful private law practice, I was appointed by President John F. Kennedy to the Federal Trade Commission. In 1964, President Lyndon B. Johnson appointed me a federal district court judge, and in 1977, President Jimmy Carter appointed me to the United States Court of Appeals for the Third Circuit. I served as Chief Judge of that court from 1989 to 1991 and as a senior judge from 1991 until my retirement in 1993. During my judicial service, Supreme Court Chief Justices Warren, Burger, and Rehnquist appointed me to a variety of judicial conference committees and other related responsibilities. I taught at the law schools of Harvard University, University of Michigan, New York University, University of Pennsylvania, Stanford University, and Yale University. By appointment of President Johnson, I served as Vice-Chairman of the National Commission on the Causes and Prevention of Violence. In 1995, I was appointed by President William Jefferson Clinton to the United States Commission on Civil Rights. Also in 1995, I received the Presidential Medal of Freedom, the nation's highest civilian award.

9 See Rosa PARKS \& Jim HASKINS, Rosa PARKS: MY StORY 1, 80-81 (1992) (Rosa Parks was a Civil Rights activist and former Secretary of the Montgomery chapter of the NAACP. She is most recognized for sparking the Montgomery, Alabama Bus Boycott in 1955.). 


\section{INTRODUCTION}

Congratulations on winning the highest office in America and completing one year of service! Your job as President is of vital importance in these tumultuous times. The unemployment rate is the highest it has been in over twenty-five years; ${ }^{10}$ the nation is involved in two military conflicts, one against the Taliban in Afghanistan and another against al Qaeda in Iraq, as we attempt to help stabilize those countries and win a "war on terrorism;" "l the incarceration rate is the highest in the world; ${ }^{12}$ and the American people are divided on how to address these problems. The country desperately needs a wise and unifying leader. And while these problems are monumental, and could be catastrophic without proper attention on your part, there is another monumental problem - this one of longstanding stature-that also must be addressed. This problem is racial inequality. ${ }^{13}$

Because you were recently awarded the 2009 Nobel Peace Prize for your "extraordinary efforts to strengthen international diplomacy and cooperation between peoples," "14 you may be thinking to yourself: "Is this man crazy? I have won both the United States presidency and the most prestigious internationally-recognized award for my ability to bring entire populations together across ethnic, class, gender, and age lines to unite for the common goals of world peace and a better future for all. How can he write about

10 Bureau of Labor Statistics Data, United States Dep't of Labor, Labor Force Statistics from the current population survey, http://data.bls.gov/PDQ/servlet/SurveyOutputServlet?data tool=latest_numbers\&series_id=LNS 14000000 (charting the national unemployment rate from 1948 to present) (last visited Nov. 30, 2009).

11 This phrase was coined by President George W. Bush in response to the al Qaeda attacks on the United States on September 11, 2001. The "war" continued throughout President Bush's two terms, and, while targeting mainly Islamic militants, also had the effect of catching other criminals unrelated to the September 11 th attacks because of an increasing web of anti-terror laws in the United States. See generally CNN.com, War Against Terror, http://www.cnn.com/ SPECIALS/2001/trade.center/ (last visited Nov. 30, 2009).

12 Adam Liptak, Inmate Count in U.S. Dwarfs Other Nations', N.Y. TimEs, Apr. 23, 2008, at A1.

${ }^{13}$ The focus of this letter will be the racial divide between whites and blacks. Other racial minorities will not be covered in the same detail as blacks. There has been much criticism concerning a failure to focus on other minority groups when explaining current disparities. To that charge I plead guilty with an explanation. It is not that the story of Latino Americans, Asian Americans, Native Americans, Native Alaskans, Native Hawaiians, and others are unimportant. On the contrary, these stories are uniquely valuable and certainly as rich and complex. Their stories deserve the same detailed treatment elsewhere that blacks receive in this letter. It is worth noting that many of the issues discussed in this letter are also relevant to the history and current situation of other racial and ethnic minorities.

14 The Nobel Foundation, The Nobel Peace Prize 2009, http://nobelprize.org/nobel prizes/peace/laureates/2009/ (last visited Nov. 30, 2009). 
inequality among races?" Your skepticism is well-placed. I am, after all, writing you from Heaven. Nonetheless, in my years of experience in the flesh I have learned that it takes much more than tremendous accolades to impact racial inequality that has persisted for centuries in our country and abroad. ${ }^{15}$

I have been studying you intently since 2006 when you rose from the unknown to become the fifth black senator to serve in the United States Congress. $^{16}$ Similar to you, I transferred in the midst of my college career to better serve my dreams of using the law to create social change. I too was the leader of a prestigious law student organization. ${ }^{17}$ I was also a fervent civil rights advocate in a working class town and the first black in a number of revered positions: partner at the first black law firm in Pennsylvania, the first black trustee of Yale University, and the first black to be appointed commissioner of a federal regulatory agency. I know all too well the constant feeling that everyone is closely scrutinizing your every move, eager to point out missteps. Believe me, this feeling will not leave you anytime soon. Your courage, dedication to the American people, and commitment to the pursuit of equality and justice, however, will sustain and energize you as you continue on this remarkable journey.

Your inauguration has ended an era in American history. When I arrived at Yale Law School as a student in 1949, a black janitor hugged me, and with tears in his eyes, exclaimed that he was so happy to see a black face in the student body. ${ }^{18}$ Now, some sixty years later, Yale Law School has had an Asian-American dean, ${ }^{19}$ and you, a black man of multiracial descent, have risen to this nation's highest political office. The America that I knew prior to my

15 In 1950, as a second-year law student, I won more oral advocacy awards than any other student in the history of Yale Law School. At the argument for the prestigious Honors Moot Court Prize, John W. Davis, the head of one of the premier law firms in the country, Davis, Polk \& Wardwell, was a judge in the competition. I was given an award as the best oral advocate. After the ceremony, Davis congratulated the three other finalists and asked each to interview at his firm. I received neither a congratulatory handshake nor an invitation to interview.

${ }^{16}$ Other black senators include: Hiram Rhodes Revels (R-MS, 1870-1871), Blanche Kelso Bruce (R-MS, 1875-1881), Edward Williams Brooke, III (R-MA, 1967-1979), and Carol Moseley Braun (D-IL, 1993-1999). After you were elected, you were succeeded by America's sixth black senator, Roland Wallace Burris (D-IL, 2009-). United States Senate, Breaking New Ground-African American Senators, http:/www.senate.gov/pagelayout/history/h_multi sections_and_teasers/Photo_Exhibit_African_American_Senators.htm (last visited Nov. 30, 2009).

17 I was a member of the Yale Law Student Moot Court Board.

18 Yale Law School admitted its first African American student in 1880, but even in 1949, I was one of only three blacks in my class.

19 Yale Law School Faculty Biography, Harold Hongju Koh, http://www.law.yale.edu/ faculty/HKoh.htm (last visited Nov. 30, 2009). A first-generation Korean-American, Harold Hongju Koh became Yale Law School's fifteenth dean in 1998 before you tapped him to join your administration as Legal Advisor to the United States Department of State. 
death in 1998, where minorities were rarely seen in the corridors of political power, is no more.

Yet, neither your swift rise to the Presidency nor the presence of any minority in a position of power marks the end of racism. Overt racism expressly sanctioned by our nation's laws has given way to covert racism, tacitly approved through color-blind policies and "race neutral" programs.

As I watched your meteoric rise to the Presidency, I was impressed by the groundswell of support you received from people in all walks of life, poor and rich, both domestically and internationally. Your Nobel Peace Prize confirms this ongoing and widespread support. Equally striking was the way in which race implicitly and sometimes explicitly affected your campaign. You have endured attacks on your name, patriotism, nationality, religion, experience, affiliations, friendships, and judgment, all unique to your status as a black man in America. So fierce were some of the attacks on your ethnicity and allegiances that you addressed the matter in a nationally televised speech from my former hometown of Philadelphia, Pennsylvania, on March 18, 2008. ${ }^{20}$

In that speech at Independence Mall, where the Liberty Bell is housed, where the Constitution was forged, where the Founders first grappled with the meaning of "life and liberty," and where I often looked from my chambers as a federal judge from 1964 to 1993, you acknowledged pride of heritage while applying the same yardstick to whites and blacks to hold both groups responsible for ongoing problems of racial inequality. What impressed me most about this speech was your recognition of our country's marred past while focusing on solutions for the future. It is this type of forward-thinking coupled with a firm grasp of the realities of racism that will allow you to continue a path forged by those in my generation.

I do not speak lightly when I say that you evoke memories of my friend and fellow civil rights leader, Dr. Martin Luther King, $\mathrm{Jr}^{21}$ The night before he was murdered, your fellow Nobel Peace Prize winner delivered a speech predicting the nation's future and his own demise. ${ }^{22}$ Dr. King prophesied that, while he likely would not live to see the day, he had no doubts that all Americans, including blacks, would some day "get to the promised land" of racial equality. ${ }^{23}$ Four decades later you have become president and gained the same international recognition as Dr. King. This achievement stirs powerful

20 Senator Barack Obama, Remarks at the Constitution Center in Philadelphia, Pennsylvania: A More Perfect Union (Mar. 18, 2008) [hereinafter Speech on Race].

21 I had the pleasure of being very dear friends with Dr. King's wife, Coretta. Coretta and I were the only black students admitted to Antioch College in 1945.

22 Martin Luther King, Jr., "I See the Promised Land" (Apr. 3, 1968), reprinted in A Testament of Hope: The Essential Writings OF MARTIN LuTHER KING, JR. 279 (James Melvin Washington ed., 1986).

${ }^{23}$ Id. 
emotions. In a country with a long history of slavery and segregation, this is truly a monumental event in the American story.

Yet, incredible barriers still exist for racial minorities in such areas as education, housing and urban development, economic power, and politics. It is difficult to imagine how those barriers can be leveled without directly tackling racism. As President, you have an opportunity to shape this country's future. Americans are counting on you to help solve the country's racial inequities and lead them to "the promised land,"24 to those "self-evident" truths of equality identified by the Founders some two hundred years ago. ${ }^{25}$

\section{YOUR IMPACT ON RACE RELATIONS}

\section{A. Changing Perceptions}

The image of a black man as the symbol of the country has already had widespread impact. People who have had little contact with blacks and could never conceive of a black man in a position of power are now faced with the reality of not only a black president, but also a black major international leader. Children who limited their goals because of their race now have a role model who can expand their possibilities. I was particularly moved by a story of the black child who asked to touch your hair to confirm its similarity to his own curly hair. ${ }^{26}$

Your election has forced many to realize that a candidate's race is not as important as his policies and beliefs. An anecdote from your campaign trail is illustrative. In the 2008 Pennsylvania Democratic presidential primary, one of your campaign canvassers knocked on the door of a house in Washington, Pennsylvania and asked the white woman resident about her choice for president. After consulting with her husband, the woman responded: "We're voting for the Nigger!"27

What is the meaning of this story? Some suggest that even bigots have priorities, and in the 2008 election the failing economy was more important than your race. Others suggest that you can put a black man in the White House, but at the end of the day-in the eyes of some-he is still inferior because he is black. Either explanation displays the complicated nature of today's racial divide. The response of the white voter from Pennsylvania reflects both the progress that has been made and one of the problems that

\footnotetext{
24 See id.

25 See THE DEClaRATION OF INDEPENDENCE para. 2 (U.S. 1776).

26 See Ebony on the Scene, EBONY, Sept. 2009, at 24.

27 James Hannaham, Racists for Obama, SALON.COM, Nov. 3, 2008, http://www.salon. com/opinion/feature/2008/11/03/racists_for_obama/.
} 
remains. The substantial number of whites ${ }^{28}$ willing to vote for a black candidate for the highest political office in the United States suggests that white racism in the political arena has decreased. Yet, the characterization of you as "the Nigger" indicates that some of your own supporters continue to view blacks negatively.

Your election will force many non-blacks to confront a duality in their own thinking: on one hand that blacks are inferior to whites, and on the other that the best person for the most prestigious job in this country is a black man. Many blacks will have to confront an analogous duality; one that leads many to believe that American structural racism prevents black success, but at the same time allows for blacks to occupy this nation's highest political office.

During the campaign, with the exception of your Pennsylvania speech, ${ }^{29}$ you generally avoided racially-charged issues, not wanting to be viewed as "the black candidate" as past minority presidential candidates had been, including Jesse Jackson. ${ }^{30}$ When controversy arose surrounding your relationship with Reverend Jeremiah Wright, ${ }^{31}$ bringing race issues to the forefront, you felt you had to address the issue directly. Such a discussion carried great risk, threatening to polarize the electorate along racial lines and jeopardize your chance to win the presidency. With much at stake, you gave an incredible speech that was ultimately considered a dramatic turning point in the election. ${ }^{32}$ You spoke directly to blacks and whites. You made whites feel that you understood their concerns about crime, education, and economic security. ${ }^{33}$ Yet, you encouraged them to acknowledge past racism and understand its

28 David Paul Kuhn, Exil Polls: How Obama Won, Politico.com, Nov. 5, 2008, $\mathrm{http}: / / \mathrm{www}$.politico.com/news/stories/1108/15297.html (describing your win of the largest share of the white vote of any Democratic presidential candidate since Jimmy Carter in 1976). Exit polls showed you at four percentage points below Carter, an incredible feat in these trying economic times. Id.

29 See Speech on Race, supra note 20.

30 Jesse Jackson, a civil rights advocate, ran for the Democratic Party's nomination for president in 1984 and 1988, receiving 1200 delegates during the second campaign and finishing second in the balloting. MARShall Frady, JESSE: The LifE AND PLLGRIMAGE OF JeSSE JACKSON 15 (Simon \& Schuster 2006) (1996). Shirley Chisholm, a Congressperson from New York City, was the first black candidate to mount a significant campaign for president receiving 151 of the over 2,000 ballots cast in the first roll call for president in the 1972 Democratic Convention. Nichola D. Gutgold, PAVING THE WAY fOR MAdAM PRESIDENT 65 (2006).

31 Jeremiah Wright is the former pastor of Trinity United Church of Christ, a Chicago church with over 8,000 members. The New Mega Churches, EBONY, Dec. 2001, at 157. Reverend Wright had delivered several provocative sermons while you were a member of his church and when this information surfaced during the presidential campaign, some began to question your relationship. Campbell Robertson, Between the Pulpil and the Pews, a Gulfon Obama's Ex-Pastor, N.Y. TMES, May 2, 2008, at A1.

32 See Speech on Race, supra note 20.

33 See Speech on Race, supra note 20. 
present effects. ${ }^{34}$ You spoke about changing the way that whites view blacks while criticizing blacks so that whites would not feel unduly burdened. ${ }^{35}$ You urged blacks to take more personal responsibility. ${ }^{36}$

In all modesty, people used to say that I could deliver a pretty good speech on race, ${ }^{37}$ but yours was truly one of the best I have heard. You dismissed the old racially-charged laments of the past as unproductive and divisive, but instead of saying, "Let's just drop the race issue altogether," you said, "Race is an issue that I believe this nation cannot afford to ignore right now." ${ }^{38}$ You urged people to start talking about race in productive ways, including how it affects education, healthcare, and economic opportunities. ${ }^{39}$ You told the American populace not to dwell on the anger of past discrimination or resentment about current programs (such as affirmative action), but instead to find solutions to real problems that have racial dimensions. ${ }^{40}$ Through this speech and other speeches by your administration, ${ }^{41}$ you bolstered your credibility with the American people (and with many of us up here in Heaven).

Many blacks, particularly those of us who lived through the Civil Rights era, never thought we would see a black president. We never believed a sufficient number of whites would vote for a black candidate. Remembering the political fates of black candidates like Harold Washington, ${ }^{42}$ Harold Ford, Jr. of Tennessee (my former student at the University of Pennsylvania), ${ }^{43}$ and Tom Bradley of California, ${ }^{44}$ many of my former colleagues and friends thought your

${ }^{34}$ See Speech on Race, supra note 20.

${ }^{35}$ See Speech on Race, supra note 20.

${ }^{36}$ See Speech on Race, supra note 20.

37 See Michael A. Fitts, In Memoriam, A. Leon Higginbotham, Jr.: The Complicated Ingredients of Wisdom and Leadership, 16 HARV. BLACKLETTER L.J. 17, 25-26 (2000).

38 See Speech on Race, supra note 20.

39 See Speech on Race, supra note 20

40 See Speech on Race, supra note 20.

${ }^{41}$ See, e.g., Eric Holder, United States Att'y Gen., Remarks at the Dep't of Justice African American History Month Program (Feb. 18, 2009) [hereinafter Holder Speech].

42 MaNnINg Marable, SPEAKIng TRUTH to POWER: EsSays ON RACE, RESISTANCE, AND RADICALISM 51 (1996). Although immensely popular, Harold Washington won the Chicago mayoral seat by only a very slim margin when members of his own Democratic party used overt racial scare-tactics that culminated in some influential politicians switching political parties to avoid supporting him as a black candidate.

${ }^{43}$ Robin Toner, In Tight Senate Race, Attack Ad on Black Candidate Stirs Furor, N.Y. TiMEs, Oct. 26, 2006, at Al. On the eve of Harold Ford, Jr.'s campaign, his Republican challenger openly race-baited the voting populace by airing a widely-viewed, extremely controversial commercial featuring Ford Jr. and an attractive white female "supporter" whom, the commercial explained, Ford Jr. had met at a "playboy party."

44 Tom Bradley was a five-time mayor of Los Angeles whose unsuccessful run for governor coined the term "the Bradley effect," describing the phenomenon where fewer whites vote for a black candidate on Election Day than polling data indicated. See Jeffrey M. Chemerinsky \& 
political career would similarly fail to attract a critical mass of white voters on Election Day. I am so glad that we were wrong.

\section{B. A New Conversation on Race}

This is not the first time that an American president has urged a "national conversation on race. ${ }^{, 45}$ President Bill Clinton did so in 1997, when he created the race initiative of "One America in the 21 st Century,", but the notion fizzled. ${ }^{47}$ As both you and Attorney General Eric Holder have noted, the same fate cannot meet your renewed call for a national conversation on race. ${ }^{48}$ It is time that America confronts its past and openly and collaboratively forges its future.

There are several dimensions to a new cross-racial understanding. One significant change could be that whites will increasingly view the conversation on race as one that is as important to them as it is to minorities. In the past, many whites viewed racial issues such as segregation, housing, and employment discrimination as solely minority concerns, something that blacks or minority immigrants-but not whites-need deal with. Now whites have begun to understand the importance of the conversation to their own wellbeing.

As the upcoming 2010 census will show, whites will soon become a minority-albeit a majority-minority, but a minority nonetheless. ${ }^{49}$ Sheer population numbers may permit many whites to change their perspectives on what have been traditionally called minority issues. But despite demographic

Kimberly C. Kisabeth, Tracing the Steps in a Historic Election, 86 DENV. U. L. REv. 615, 623 \& n.43 (2009).

45 'A Nation of Cowards'?; The Attomey General's Speech on Race, WASH. Post, Feb. 21, 2009, at A12.

46 President Clinton's One America in the 21st Century, About the Initiative, http://clinton4.nara.gov/textonly/Initiatives/OneAmerica/about.html (last visited Nov. 30, 2009). President Clinton's Race Initiative for One America was designed to "strengthen our shared foundation as Americans so that we can live in an atmosphere of trust and mutual respect." President Clinton's One America in the 21st Century, Overview, http://clinton4.nara.gov/text only/Initiatives/OneAmerica/overview.html (last visited Nov. 30, 2009). By inviting critics of America's racial practices and policies including John Hope Franklin to chair committees, the initiative aimed to create an understanding about racial frustrations. By focusing on specific national issues, Clinton hoped to learn more about America's racial problems and reach targeted solutions. Established in 1997, the project produced a number of reports but was largely dissolved by 1998.

47 Nation of Cowards, supra note 45.

48 See Holder Speech, supra note 41.

49 See Press Release, U.S. Census Bureau, An Older and More Diverse Population by Midcentury 1 (Aug. 14, 2009), http://www.census.gov/Press-Release/www/releases/archives /cb08-123broadcast.pdf. 
changes, whites still comprise a controlling voting block and are overrepresented in national and state congresses. As such, you must be careful not to alienate this group as a whole. If white political and economic dominance are perceived to be "unfairly" threatened, there could be conflict fueled by white resentment. So you must be very careful to formulate issues in ways that will not make whites feel unduly challenged politically, economically, or socially. This will require careful balancing on your part. Issues perceived as impacting white dominance, such as affirmative action, must be couched in non-threatening terms. Poverty-based efforts, in conjunction with racially-based ones, may reduce such feelings of anxiety. This is imperative because racial polarization would undermine your coalition significantly.

Another potential response to the renewed racial dialogue is one that we have seen already: the blank stare of incredulity. Some will think, "What conversation on race?"; or "Racism is over; we have a black president." Your election symbolizes the start of a "post-racial" America for many, one in which race as a salient factor ceases to exist. ${ }^{50}$ But you know better. It will take a concerted effort to undermine this sentiment. No domestic or international acclaim will bring an end to racial hatred or inequality. Your domestic policies should be made with a focused understanding of their racial effects as appropriate. You must continue to counter the idea that your election had the magic $^{51}$ effect of ameliorating centuries of racism and segregation. As you receive praise worldwide, you must remember that covert racism unfettered by government action could prevent many youngsters from seizing the same opportunities that allowed you to stand before 1.8 million Americans, the largest crowd ever assembled on the Washington National Mall, ${ }^{52}$ and take the oath of office on January 20, 2009.

50 See, e.g., Jonah Goldberg, Why Obama also Gives Hope to Conservatives, CHI. TRIB., Jan. 22, 2009, at C31; John O'Sullivan, Comment, Obama the Enigma Must Point the Way to the Future; The Arrival of a New President Has United Americans in a Mood of OptimismDespite the Economic Crisis. Will His Inaugural Speech This Week Justify Their Faith in Him?, SUNDAY TElEgRAPH (London), Jan. 18, 2009, at 22; Jonetta Rose Barras, The Man of Tomorrow: He Leapt the Tallest Barrier. What does it Mean for Black America?, WASH. PosT, Nov. 9, 2008, at B01 (Md. regional ed.).

51 See David Ehrenstein, "Magic Negro" Returns, L.A. TomES, Mar. 19, 2007, at A13 (noting that during the 2008 election you were referred to as the "magic Negro" for your ability to help whites rid themselves of the guilt many associate with slavery). So popular was the moniker that the Republican Party named a song after you at their national convention and talk show host Rush Limbaugh played it on his show. See Posting of John Aravosis to Americablog, http://www.americablog.com/2007/04/barack-magic-negro-new-song-played-on_30.html (Apr. 30, 2007, 09:34:00 EST).

52 Michael E. Ruane \& Aaron C. Davis, D.C.'s Inauguration Head Count: 1.8 Million, WASh. Post, Jan. 22, 2009, at B1. That crowd included my 84-year-old cousin, Robert 


\section{THE UNIQUE OPPORTUNITY FOR THE FIRST BLACK PRESIDENT TO SUCCESSFULLY CONFRONT RACIAL ISSUES STILL FACING AMERICA}

As President, you must create and support programs that encourage black personal responsibility and prevent white isolationism. Whites cannot opt out of the collective responsibility to create equality. Blacks must opt into a system that they believe has repeatedly diminished their opportunities. You can create a more fair system that accounts for racial discrepancies, but is not seen as giving "free handouts" to undeserving individuals.

Racial inequality today is much more complex than it was when Dr. King led protests. Forty years ago, our nation's laws enshrined discrimination and violence was used to maintain the divide. Today such inequality results from inadequate anti-discrimination laws, inequitable school funding, housing isolation, economic exploitation, criminal justice stereotyping, and political underrepresentation. If true racial equality is ever to be achieved, the "hearts and minds" of the American people must change first.

\section{A. Helping Blacks Examine Race-Based Ideologies}

Your 2008 Father's Day speech encouraging black male familial responsibility was inspiring. ${ }^{53}$ As many people in black elite, older generations, and academia have noted, as a community, blacks need to foster a culture of responsibility for their actions. ${ }^{54}$ More recently, dispatching Attorney General Eric Holder and Secretary of Education Arne Duncan to Chicago, to address issues of gang violence in urban schools, continues to convey the proper messages of personal responsibility, the value of education, and deploring violence. Without a serious change in how blacks view their own destinies (as being at least to some extent out of their control due to white racism), it will be impossible to have a constructive conversation on race or to improve racial equality in this country.

Without stifling the creativity of musicians, it is time to hold them accountable for self-hating messages and demonization of our rich culture and

Higginbotham, and several dozen of his fellow Tuskegee Airmen, who you commendably invited to the ceremony in recognition of their outstanding combat record and civil rights commitments during World War II.

53 President Barack Obama, Remarks on Father's Day 2008 at the Apostolic Church of God in Chicago, Illinois (June 15, 2008).

54 Indeed, the "grandfather" of the movement for black familial responsibility, Bill Cosby, my friend and fellow Philadelphian, made a similar speech in 2004 at the NAACP's commemoration of the Brown v. Board of Education, 347 U.S. 483 (1954), decision. Bill Cosby, Address at the NAACP on the 50th Anniversary of Brown v. Board of Education (May 17, 2004). 
traditions. Many hip hop artists produced songs and commercials to support you. This is a step in the right direction. Perhaps you can use your influence to encourage musicians, including T.I. (who appeared with you on the campaign trail), to produce more positive music and be positive role models. At the same time, you should not ignore the profound nihilistic messages espoused by many of the hip hop generation. While I personally preferred the jazz greats such as my relative J.C. Higginbotham, Miles Davis, Ella Fitzgerald, and Duke Ellington, I realize that, among others, T.I., Jay-Z, Mos Def, Beyonce, and Erykah Badu bear witness for a new generation. The themes of many of their songs provide a voice for the unseen, ignored, and marginalized "invisible" men and women of the Twenty-First Century. In the same way that they could learn from your example and continued encouragement of black personal responsibility, you would do well to listen to their messages and keep them in mind as you forge policies affecting their admirers and yours. You must continue to encourage black personal responsibility through your words of wisdom and by example.

Your presence on the international stage and the image you project will continue to have a tremendous impact in combating stereotypes. Due to negative media presentations and prejudice, perceptions of blacks include broken families, excessive criminality, and widespread drug abuse. High visibility of you and your family, who defy those racially stereotypical images, undermines negative perceptions of blacks. Whether you like it or not, perceptions carry great weight, and to that end you must remain above reproach in your display of family values. A Clinton-era-type misstep on the homefront could prove disastrous. The tendency of Americans to generalize your family experiences as those of blacks throughout the country is too great to put into jeopardy. Without a doubt, this standard is unfair, but the American racial paradigm cannot be ignored. As you are aware, that entails blacks being considered an "exception" while portraying excellence, but "the rule" while portraying something negative. Merely by your example, you have already begun to move the baseline for "the rule." It will be up to your sound decisionmaking and groundbreaking policies to ensure that your legacy is not viewed as an "exception."

\section{B. Helping Whites Change Problematic Racially-Based Behavior}

White privilege must be stopped by whites themselves. A failure to acknowledge structural racism, white isolationism and overvaluation, and black marginalization ignores the reality of current American race relations. Crossracial dialogue is made difficult by the suggestion that racism is no longer a factor in determining opportunities, even though it is admittedly much less of one today than in the past. 
The debate over affirmative action provides an excellent example. Some states, such as California, have forbidden race from being used as a factor in admissions to public colleges or universities. ${ }^{55}$ Yet, these same states allow a preference for children of alumni even when blacks were excluded from those schools in the past or did not attend in large numbers. Under such circumstances, prohibiting a preference for under-represented blacks while permitting a preference for children of mostly-white alumni embraces the notion of white superiority and maintains inequality, even though on its face it appears race-neutral. This is especially problematic because statistics indicate that black students admitted under affirmative action programs perform well in terms of grade-point-averages and graduation rates. ${ }^{56}$

In addition to eliminating the embrace of white notions of superiority, whites must speak out against racial wrongs when they see them. Speaking out will ensure that notions of white superiority are not reinforced. Silence implies acceptance.

Evidence suggests that whites are changing. For example, racist references about your being an "affirmative action" candidate or being "the black candidate" were roundly condemned by an increasing number of whites. ${ }^{57}$ Much of this condemnation comes from whites under forty years of age, who have grown-up in a post-Brown ${ }^{58}$ environment. ${ }^{59}$ They have lived, gone to school, and worked with significant numbers of blacks. Whites who have had such interaction tend to be more outspoken against racism than other whites. You, President Obama, must encourage such outspokenness. In the same way that it will be impossible to forge a new multiracial America without an attitude change among significant numbers of blacks, it will be as difficult to do so without having many whites confront their own personal prejudices.

\section{The Recommended Approach}

I would suggest an approach that utilizes the transformative power of the law. Color blind and race-neutral approaches to the racial divide are inadequate, in light of the continuing notion of white superiority. Radical changes are necessary to alter long-held notions of white superiority. Racist choices camouflaged in neutral-sounding rules and practices must be prevented.

55 CAL. CONST. art. 1, § 31. This provision was added by initiative measure Proposition 209. 1996 Cal. Legis. Serv. Prop. 209.

56 See generally WILLIAM G. BOWEN \& DEREK BOK, THE SHAPE OF THE RIVER: LONG-TERM CONSEQUENCES OF CONSIDERING RACE IN COLLEGE AND UNIVERSITY ADMISSIONS (2000)(1998).

57 Searching for the Promised Land; Race in Obama's America, ECONOMIST, Dec. 6, 2008 (U.S. ed.).

58 See Brown v. Bd. of Educ., 347 U.S. 483 (1954).

59 Searching for the Promised Land, supra note 57. 


\section{Anti-discrimination policies and practices}

By equalizing public school funding, passing inclusionary housing laws, and implementing affirmative action programs, for example, you can make concrete differences in the lives of everyday Americans. You can accomplish these changes through unilateral executive orders, encouraging congressional action, and Supreme Court appointments.

If the opportunity presents itself to replace one or more of the five conservative justices on the Court, you must make certain that you replace them with individuals committed to the belief that government can play a significant role in creating racial justice. Since so many decisions on racial justice issues are five votes to four, replacing one conservative justice could alter the entire direction of the Court and reshape equality law for generations. Your recent nomination of Judge Sonia Sotomayor to replace retiring Justice David Souter on the Supreme Court was a wise choice. While unlikely to alter the direction of the court on racial equality issues since Justice Souter was a reliable vote for the liberal wing of the court, Judge Sotomayor's long and distinguished career reflects a commitment to equal justice reminiscent of past liberal justices like William Brennan, whom I have referred to as possessing "extraordinary wisdom and compassion.",60

Some have criticized now-confirmed Justice Sotomayor for lacking the proper judicial temperament. In particular, these critics have focused on her remarks honoring another judge who had died prematurely. Then-Judge Sotomayor stated: "I would hope that a wise Latina woman with the richness of her experiences would more often than not reach a better conclusion than a white male who hasn't lived that life." Critics such as Newt Gingrich and Rush Limbaugh have referred to then-Judge Sotomayor as "a Latina racist," a very serious charge if true. ${ }^{61}$

As a federal judge in 1974, I faced a similar charge. In Union of Operating Engineers, ${ }^{62}$ I responded to a motion asking that I recuse myself because I was black. This was a civil rights employment action brought by black construction workers against two contractors associations. The defendants moved for my recusal specifically because of comments that I had made while speaking at a luncheon organized by the Association for the Study of Afro-American Life and History. At the luncheon I stated that African Americans could no longer rely exclusively on the Supreme Court as an instrument for social change. In

\footnotetext{
${ }^{60}$ Higginbotham, Jr., supra note 2, at 1008.

61 Newt Gingrich subsequently apologized for this characterization, but Rush Limbaugh reiterated the charge. Tom LoBianco, Gingrich Retreats on "Racist" Charge Against Nominee; Challenge Her Record, He Says, WASH. TMMES, June 4, 2009, at A07.

${ }^{62}$ Commonwealth v. Local Union 542, Int'l Union of Operating Eng'rs, 388 F. Supp. 155 (E.D. Pa. 1974).
} 
responding to this recusal motion, I explained that the presence of bias-not skin color-should be the determining factor for recusal. ${ }^{63}$ I explained:

I concede that I am black. I do not apologize for that obvious fact. I take rational pride in my heritage, just as most other ethnics take pride in theirs. However, that one is black does not mean, ipso facto, that he is anti-white; no more than being Jewish implies being anti-Catholic, or being Catholic implies being anti-Protestant. ${ }^{64}$

I spoke from the heart in that opinion, and indicated that I was a proud black man who understands and appreciates the obstacles, sacrifices, and accomplishments of those African Americans who had fought and in some cases died for freedom and equality. This recognition did not make me antiwhite. I spent my entire professional career writing, speaking, and treating all individuals-irrespective of race-as equal and respected members of the human family. ${ }^{65}$ I was not going to allow wealthy and powerful white litigants to characterize me as less objective than white judges merely because I happened to be black.

Similarly, merely because Justice Sotomayor acknowledges that experiences, including racial ones, may influence judgment does not mean that she is racist. As with my recusal decision in 1974, much more would need to be established to indicate even the possibility of bias than this reflective remark. Of course experiences - both positive and negative-influence judgment, which is why I have always felt that values should be the most important factor in judicial

${ }^{63}$ Id. at $159-60$.

64 Id. at 163.

${ }^{65}$ See F. Michael Higginbotham, Speaking Truth to Power: A Tribute to A. Leon Higginbotham, Jr., 20 Y ALE L. \& POL'Y REv. 341 (2002); Colleen L. Adams et al., A Life Well Lived: Remembrances of Judge A. Leon Higginbotham, Jr.-His Days, His Jurisprudence, and His Legacy, 33 LOY. L.A. L. REV. 987 (2000); Margaret Chon, A Symposium Tribute to Judge A. Leon Higginbotham, Jr.: The Mentor and His Message, 33 LoY. L.A. L. REv. 973 (2000); L. Barry Costilo, An Unforgettable Year Clerking for Judge Higginbotham, 33 LoY. L.A. L. REV. 1009 (2000); Michael A. Fitts, The Complicated Ingredients of Wisdom and Leadership, 16 HARV. BLACKLETTER L.J. 17 (2000); Henry Louis Gates, Jr., Remembering Leon, 6 HARV. J. Afr. AM. PUB. PoL'y 1 (2000); Clifford Scott Green \& Stephanie L. Franklin-Suber, Keeping Thurgood Marshall's Promise-A Venerable Voice for Equal Justice, 16 HARV. BLACKLETTER L.J. 27 (2000); F. Michael Higginbotham, A Man for All Seasons, 16 HARV. BLACKLETTER L.J. 7 (2000); F. Michael Higginbotham, Promises Kept, 6 HARV. J. Afr. AM. PUB. POL'Y 11 (2000); F. Michael Higginbotham \& Jose Felipe Anderson, A Tribute to Judge A. Leon Higginbotham, Jr.: Who Will Carry the Baton?, 33 LoY. L.A. L. REv. 1015 (2000); Joseph S. Nye, Harvard Farewell, 6 HARV. J. AFr. AM. PUB. POL'Y 5 (2000); Mitsi Sellers, Working with the Judge, 6 HARV. J. AFR. AM. PUB. POL'y 7 (2000); Charles J. Ogletree, Jr., in Memoriam, A. Leon Higginbotham, Jr., 112 HARV. L. REv. 1801 (1999); William J. Brennan, Jr., Tribute to Judge A. Leon Higginbotham, Jr., 9 LAW \& INEQ. 383 (1991); Cliff Hocker, A. Leon Higginbotham: “A Legal Giant", NAT'L B. Ass'N MAG., Mar.-Jun. 1999, at 16. 
selection. Justice Sotomayor is hardworking, bright, experienced, and, most importantly, committed to values, such as the rule of law, the principle of democracy, and the rights of due process and equal protection. These are some of the same values that have made the United States the great country that it is today. That is why I believe that her nomination and confirmation were appropriate. President Obama, you must make certain that any future minority nominees are examined carefully and thoroughly, but under the same standards as those white nominees recently confirmed, whose values were deemed by members of the Senate to be acceptable for service on the Supreme Court. ${ }^{66}$

Should the Supreme Court fail to change its jurisprudence on race-conscious remedies, you should encourage Congress to pass new laws fostering racial equality. The first step is for Congress and state legislatures to ensure that the American people know the full story of our nation's racial oppression, as well as its successes. Information is empowering. The truth will serve to undermine negative stereotypes by revealing how and why they were created. What is required is an accurate education on the history of racism, including depictions of slavery, Reconstruction, and segregation, and acknowledging - rather than hiding-statistics that demonstrate high rates of discrimination. Often our nation's history classes and books omit the horrendous treatment that minorities endured and continue to face. ${ }^{67}$ A congressionally-sponsored truth commission should be created that will go beyond the Civil Rights Commission, which I served on in the mid-1990s, to provide advice and guidance to the president.

${ }^{66}$ When then-Judge Samuel Alito, my former colleague on the United States Court of Appeals for the Third Circuit, was confirmed to the Supreme Court in 2006, my name was invoked in error by Alito supporters even though I had passed away some eight years earlier. I have pleasant memories of the occasions in which Alito appeared before me as a lawyer. I often remarked to colleagues that he was one of the best appellate advocates that had ever come before me on the bench. His oral arguments were clear, well-reasoned, and conveyed in a forthright manner. His briefs were thoroughly annotated, carefully structured, and intricately detailed. Alito's work ethic was equally apparent in the few years that he and I sat together as colleagues on the Third Circuit Court of Appeals. Then-Judge Alito's Supreme Court nomination confirmation hearings served to remind me of those times. He was a valued colleague whom I respected for his intellect, integrity, and dedication, and I knew first-hand that he possessed the ability to be a superb Supreme Court justice. While Alito's ability was beyond question, his approach to adjudicating individual rights-insofar as I could discern it from his record as a lawyer and a judge - gave me some cause for concern. At the time of then-Judge Alito's nomination, prior to and during the confirmation hearing, a senator and a witness invoked my name to suggest that had I been living I might not have opposed the nomination. Let me now set the record straight. Although I regard Justice Alito with great respect, this suggestion could not have been further from the truth. See Michael Higginbotham, Setting The Record Straight: Judge Higginbotham on Judge Alito, BALTIMORE AFrO-AMERICAN, Jan. 28, 2006, at A11; cf. infra note 109.

${ }^{67}$ See A. Leon Higginbotham, Jr., The Bicentennial of the Constitution: A Racial Perspective, STAN. LAW., Fall 1987, at 8. 
You can create such a truth commission to identify issues, hold hearings, facilitate discussion, and promulgate recommendations to federal and state agencies. You should hold radio or town hall meetings that focus on an aspect of the racial divide that would allow for discussion of both the past and the present. President Franklin Delano Roosevelt held "fireside chats."68 You could hold "town hall meetings for equality." I recognize that this path is risky, potentially opening up racial "wounds" that could exacerbate tensions among races. Given the recent actions of some Republicans bent on de-railing your healthcare plan at town hall meetings, perhaps this format will need to be revamped and reconsidered. ${ }^{69}$ Yet, I am comforted by your amazing ability to bring people together across racial lines. As you did at the White House with respect to the dispute between my good friend, Professor Henry Louis Gates, and the Cambridge, Massachusetts Police Officer who arrested him, you could facilitate a discussion on a larger and more comprehensive scale.

For some whites, you are the right shade of blackness; light "enough" and of mixed race, thus reducing the stigma that blackness carries in America, and at the same time, dark enough to be black when you won the presidency so that Americans could embrace the accomplishment of electing a minority for the first time. For many blacks you were almost too "white," but black enough to be considered one of their own.

Your international heritage positions you to call on the international community to fight racism worldwide. A global initiative would be wellreceived within the United Nations and in many countries such as South Africa, Brazil, Cuba, and Australia. Navanethem (Navi) Pillay, the United Nations High Commissioner for Human Rights (whom I worked with closely in the 1980s on anti-Apartheid efforts), has called for such an approach. You must recognize that no president since Nelson Mandela ${ }^{70}$ has had the potential to have greater international impact. In 1994, when Mandela asked me to come to South Africa to mediate a South African election dispute between several rival political parties, we joked that no one (not even I, who was known for judicial bridge-building) was better than him at creating and solidifying cross-racial coalitions. You, like Mandela, must use your image as an asset and attack racism by building international coalitions in ways that no other American president has or could. You have already begun this process with an overture to Cuban President Raul Castro. ${ }^{71}$

68 See FDR's FIRESIDE ChATS (Russell D. Buhite \& David W. Levy eds., 1992).

69 Kathleen Gray \& Dawson Bell, Passionate Debaters Stir Up Health Care Town Halls: Lawmakers Get a Fight, DETROrT FREE PrESS, Aug. 13, 2009, at 1 A.

70 Nelson Mandela was the first democratically-elected president in post-apartheid South Africa.

${ }^{71}$ Obama, Raul Castro Start to Thaw Relations Between U.S. and Cuba, CAN. BroADCASTING CORP., Apr. 17, 2009, www.cbc.ca/world/story/2009/04/17/cuba-obama-castro 
This is a wise beginning, but you missed a wonderful opportunity when you boycotted, albeit "with regret," the United Nations' Conference on the Elimination of Racism. ${ }^{72}$ While you were correct to oppose excessively harsh language against Israel included in the conference's final declaration, and State Department Deputy Spokesperson Robert Wood stressed the United States' continued commitment to "halt racism and discrimination wherever it occurs," your boycott of the conference was inconsistent with your conciliatory strategy abroad. You have offered an open hand in exchange for an unclenched fist when it comes to a new foreign policy approach. ${ }^{73}$ As you did with Cuba, you must engage first before you decide to say "no" to coalition building on racism internationally.

\section{Education}

Another important goal must be the equalization of the quality of public schools throughout the country. This should include increased spending per pupil in the poorest districts. The constitutional promise of equal education for which Thurgood Marshall fought so fervently as an attorney in Sweatt $v$. Painter, ${ }^{74}$ and subsequently in Brown v. Board of Education, ${ }^{75}$ is not being adequately protected by the judiciary. Today, the series of school desegregation decisions, including the recent Parents Involved ${ }^{76}$ case, have basically eviscerated the Fourteenth Amendment's equality guarantee to the extent that it applies to primary and secondary public education. ${ }^{77}$ The current trend in Supreme Court jurisprudence to prevent government-backed raceconscious remedies aimed at decreasing racial segregation is clear. ${ }^{78}$

You must take an alternate route that does not merely support affirmative action programs to the extent that they remain necessary in both secondary and university contexts. You must also fundamentally rethink the way that this

016.html.

72 Matthew Lee, Obama to Boycott U.N. Conference on Racism, VIRGINIAN-PILOT, Apr. 19, 2009, at A3.

${ }_{73}$ President Barack Obama, Inaugural Address (Jan. 20, 2009).

74 Sweatt v. Painter, 339 U.S. 629 (1950) (holding that the separate black law school was not "substantially equal" to the law school of the University of Texas, thus making petitioner's rejection from the law school of the University of Texas unconstitutional). In my first year of law school I was fortunate enough to watch the great Thurgood Marshall argue on behalf of Heman Sweatt before the United States Supreme Court in Sweatt.

75 Brown v. Bd. of Educ., 347 U.S. 483 (1954).

76 Parents Involved in Cmty. Sch. v. Seattle Sch. Dist. No. 1, 551 U.S. 701 (2007).

77 See, e.g., id. (holding that in the primary and secondary school context, absent vestiges of segregation, the use of racial classification schemes to achieve "diversity" broadly defined is unconstitutional).

78 See, e.g., id. 
country funds and provides education. You have said that you will begin by providing additional funding to the important but practically unfunded "No Child Left Behind" program. ${ }^{79}$ You and Secretary of Education Arne Duncan should devise a method for low-performing students to receive the assistance they need. In a time when, as you put it, our "nation's schools are crumbling, ${ }^{, 80}$ we need creative solutions that create opportunities for those most harmed by the continuing effects of de facto segregation, rather than merely shift funding around. You must find a way to strike the proper balance reflecting both merit in assessing educational achievement and, at the same time, leveling the playing field for America's black students. You can achieve equality in education by ending school funding based on property taxes. Instead, promote an educational equity law that requires equal funding for all public primary and secondary schools, and provides economic incentives and rewards for previously under-funded districts when those districts excel. Doing so will help traditionally disadvantaged and disenchanted minority students, ${ }^{81}$ and at the same time create an opportunity for all American students to become globally competitive.

Your presence alone is inspiring. Your presidential campaign success had such a potent effect that it has been coined the "Obama effect." a Vanderbilt University study, black test-takers who usually perform worse than their white peers when tests identify their race, performed better or at the same level as their white peers when administered a test directly after your election. ${ }^{83}$ It seems that your symbolic inspiration helps improve the self-esteem and abilities of black test-takers who normally worry that their results will be considered a reflection of their race. The results of this preliminary study are certainly encouraging and speak volumes. You have an incredible opportunity to change the educational landscape in this country and you should affirmatively embrace it.

79 See BarackObama.com, Organizing for America-Education, http://www.barack obama.com/issues/education/ (last visited Nov. 30, 2009).

${ }^{80}$ Speech on Race, supra note 20.

81 See Hazel Trice Edney, blackvoicenews.com, New "Doll Test" Produces Ugly Results, Aug. 21, 2006, http://www.blackvoicenews.com/content/view/39840/16/ (discussing an experiment where a preschool-aged black girl selects a black doll as one that "looks bad" relative to a white doll, and yet acknowledges that the black doll looks more similar to herself).

${ }^{82}$ Sam Dillon, Study Sees an Obama Effect as Lifting Black Test-Takers, N.Y. TIMES, Jan. 23, 2009, at A15.

${ }^{83} \mathrm{Id}$. 


\section{Housing and urban development}

Housing and urban development are probably the two areas where the lasting effects of slavery and segregation are most visible. Reflective of this is whites' continual embrace of the "tipping point" notion in housing integration. Instead of forging communal ties with their new neighbors, many whites associate the mere presence of blacks in their homogeneous communities as both a threat and an indication of a decline in property value, so they flee their neighborhoods for less diverse suburbs. "Tipping point" bigotry was exemplified by Jeremy Parady, who plead guilty in 2005 to conspiracy to commit arson in a new housing development because many of the buyers were black. ${ }^{84}$ Parady admitted that he set fire to this development because many of the buyers were blacks and the surrounding neighborhood was mostly white.

Furthermore, urban development schemes tend to benefit community outsiders, and, to the extent that they are successful, they have a tendency to drive out minority residents from their urban center homes. I think you are on the right track with your plans to create more low-income housing opportunities, stimulate economic prosperity, and fund community development projects. You can go one step further by providing special grants, tax cuts, or funding for current community residents to start or continue operating businesses in economically-depressed neighborhoods. This would help keep long-time residents in renewing neighborhoods while fostering an environment of success and achievement among urban minorities.

Publicly-financed housing projects must be strategically located to facilitate racial integration-not segregation, as they have in the past. Housing laws should mandate such strategic locations and this mandate should be vigorously enforced. Integrated housing is crucial to reduce the racial divide because so many of life's activities, especially education, revolve around communities. If Americans are racially divided in housing, they are likely to be divided in other areas of life. You have the tools in your box to truly transform the face of America. You should seize the opportunity to re-integrate and reinvigorate our urban communities. With Congress on your side, you can literally transform "Main Street."

\section{The economy}

Economic inequities must be substantially reduced. White high school graduates are more likely to be hired than black college graduates and white college graduates are more likely to be hired than blacks with doctorate

${ }^{84}$ Gary Gately, Pall of Racism Remains Over Neighborhood Repaired After Arson, N.Y. Times, Oct. 6, 2005, at A16. 
degrees. ${ }^{85}$ This must change, for the maintenance of these economic inequities makes bridging the racial divide virtually impossible. Anti-discrimination laws in employment must be strengthened by reducing burdens of proof for plaintiffs and increasing monetary penalties and criminal sanctions for violators.

I am pleased by the announcement of your economic stimulus plan. I know that you have learned from the mistakes made while you were in Congress. You realize that providing lump sum payments to banks without restrictions will not do the most to help the American people. Words cannot convey the level of despair I felt when I saw the video of the California man, Robert Daniel Webb, who was recently laid off from his job, hold up a drug store cashier at gunpoint while Webb's nine-year-old daughter watched in disbelief. ${ }^{86}$ As you implement your desperately needed plan to help America's working and middle classes, be sure to focus on the workers themselves. Those who toil tirelessly in factories and those who are seeing their jobs disappear need your help even more than the nation's bank executives. You must devise a way to re-educate them to put their human capital to the hard work of building America for the Twenty-First Century and beyond. Collectively, Americans have always been a creative and hardworking people. Give them the chance to show these traits to the world once again.

As a leader in developing technology, America has the unmatched capability to retrain and retool the same factories that gave us a thriving middle class and assured our economic prominence in the world. Your focus on green technology and innovation is astute and could help re-employ thousands of jobless Americans. Your creation of a "Green Jobs Czar" certainly shows that your focus is in the right place. But do not forget that it was the manufacturing industry-auto, steel, railroads, and mining-not banks, Wall Street, or hedge funds that gave blue-collar workers their first jobs and a chance for a better economic future.

When blacks were blocked from other trades and employment opportunities, it was the manufacturing industry that opened its doors. Now that this industry is failing, you can expect a decline in the black middle class that nourished you, economically and emotionally, throughout much of your presidential campaign. While some in the United States would simply like to ignore the casualties in working class towns like Philadelphia, Chicago, and Detroit, retraining those who helped build this country to create a new technologically-advanced and environmentally friendly nation will serve you better than continuing to open government coffers to banks and other financial institutions.

${ }^{85}$ National Urban League, State of Black America RePort 2006 (Stephanie R. Jones \& George E. Curry eds., 1998).

${ }_{86}$ Man Robs Store with 9-Year-Old Daughter in Tow, NBC News \& News Service, Apr. 2, 2009, http://www.msnbc.com/id/30013901. 
As a former Commissioner of the Federal Trade Commission (FTC), I am concerned that your focus on jobs "shipped offshore" is a bit short-sighted. In a globalized economy it will be inevitable that certain types of jobs will either exist beyond national boundaries or become obsolete. Stoking the fires of xenophobia will not create new American jobs; it could, however, exacerbate racial tensions. I am reminded of the Vincent Chin incident when Detroit was facing drastic job cuts in the 1980s, and I see striking similarities with today's economic climate. ${ }^{87}$ Chin was killed in racially-charged riots directed at recent immigrants. The same climate that led to Chin's death is fomenting throughout the country today. As the United States' demographics change, alienating ethnic groups by focusing on job losses to other nations will create new ethnic divides that America does not need. Your support of the Dream Act, which allows undocumented college graduates of American universities who are longterm residents of the United States to acquire lawful resident status, would be a step in the right direction. ${ }^{88}$

\section{Criminal justice}

On the eve of your inauguration an unarmed black man was killed by the Oakland transit police while laying face down, sparking riots reminiscent of those that occurred in the 1960s. ${ }^{89}$ Several months before that, three New York City police officers were acquitted after being arrested for killing another unarmed black man on his wedding day in 2006 in Queens, New York. ${ }^{90}$ These stories are shocking, painful, and unfortunately all too common. Police brutality, if not on the rise, is at least as prominent now as it was when I served as an Assistant District Attorney in Philadelphia in the early 1960s. To make matters worse, the perpetrators who use excessive force--predominately against black men - seem to escape any sort of criminal punishment. This must stop.

The integrity of our police force is instrumental to the function of our society. If a few police officers are permitted to be criminals in blue uniforms and immune to the strictures of our criminal justice system, we can expect more fatal "mistakes," more riots, and a citizenry increasingly mistrustful of state

87 See generally American Citizens for Justice, Home, http://www.americancitizensfor justice.org/ (last visited Nov. 30, 2009). American Citizens for Justice is an organization dedicated to restoring justice in the Vincent Chin case and preventing similar racial injustice.

88 See Development, Relief, and Education Act for Alien Minors Act of 2009 (DREAM Act of 2009), S. 729, 112 th Cong. (2009).

89 Sean Maher, New Video Shows BART Officer Shooting Hayward Man in the Back, CONTRA Costa Times (Cal.), Jan. 4, 2009, at My Town; Alameda.

90 Michael Wilson, Judge Acquits Detectives in 50-Shot Killing of Bell, N.Y. TIMES, Apr. 26, 2008, at A1. 
authority. The police have been allowed for many years to embrace strategies that employ racial profiling and curb civil liberties. As Vice-Chairman of the National Commission on the Causes and Prevention of Violence in 1969, I disagreed with a majority of Commission members by including dissenting language in the report that nonviolent protests paved the way for the elimination of Jim Crow practices. ${ }^{91}$ As the Chief Executive, it is time for you to send a strong message that these policies are unacceptable and will not be tolerated in the post-racial America that you hope to forge. The risk that such policies will continue to lead to fatalities and discrimination is too great.

Harsher criminal punishment for blacks is common, even today. National statistics indicate that blacks are prosecuted and imprisoned at a rate more than five times that of whites. Blacks are arrested at rates several times that of whites, are less likely to receive prosecutorial discretion in the courtroom, and often receive longer sentences than whites for identical crimes. The stories of Tim Carter and Richard Thomas exemplify this inequality. Both men were arrested in 2004, "in separate incidents, three months apart, in nearly the same location." "Police found one rock of cocaine on Carter, who is white, and a crack pipe with cocaine residue on Thomas, who is black. ${ }^{, 93}$ Neither had prior felony arrests or convictions, and both claimed drug addictions and potentially faced five years in prison. ${ }^{94}$ Carter's prosecution was withheld and the judge sent him to drug rehabilitation. ${ }^{95}$ Thomas was prosecuted, convicted, and jailed. ${ }^{96}$ Their only apparent difference was race.

While you provide hope for anyone who wants to succeed in this country, the potential role models from urban homes are increasingly being taken away, locked up, and forgotten. In early April, Attorney General Eric Holder made it clear to all federal prosecutors that such bias was unacceptable and would not be tolerated. ${ }^{97}$ This is a much needed step in the right direction as our jails are disproportionately filled with black men.

Many murders of civil rights workers that occurred during the Jim Crow era remain unsolved, however, because of the lack of rigorous investigation at the time the crimes were committed. Modern forensic techniques, along with a renewed commitment by law enforcement, could bring about justice that would

91 See To Establish Justice, to InSURe Domestic Tranquility: Final RePort of THE National Commission on the Causes and Prevention of Violence 87, 108-18 (1969).

92 Eric Lotke, Joint Center for Political and Economic Studies, Racial Disparity in the Justice System: More Than the Sum of its Parts Bias Infects System from Investigation to Incarceration, Focus MAG., May-June 2004, at 3-4.

93 Id.

94 Id.

95 Id.

9 Id.

97 Eric Holder, Att'y Gen., Remarks at the National Black Prosecutors Association's Profiles in Courage Luncheon (July 22, 2009). 
create goodwill and start a healing process. Solutions must not stop with prosecutions of elderly white racists who have ceded their leadership positions in terrorist organizations such as the Ku Klux Klan to other younger members. The government must demonstrate a commitment to racial justice in new racial hatred cases as well.

Tackling racism in the criminal justice system, though near to your heart as a lawyer by trade, will be extremely difficult from your position. That said, while occupying the highest office in the land your words carry great weight. You have already condemned the state of the criminal justice system in America as a presidential candidate. It is time that you do it again. It is no time for "politics as usual" when it comes to these matters of life and death. You must send a strong message that indiscriminate killing of young black men is not a statesanctioned activity and provide district attorneys, judges, and other professionals with viable alternatives to incarceration for non-violent criminals.

\section{Politics}

Although you are one of the rare exceptions thus far, white reluctance to support black candidates has made successful state and national black candidacies scarce. In fact, that race needed to be "transcended" for your candidacy to garner enough support reinforces the central premise that racism still haunts the political arena. Black candidates continue to be hyperscrutinized for their endorsements and associations former and current (aside from their policies), because of a fear that they may have hidden racial biases. Even their supporters face questions.

For example, when Republican and retired General Colin Powell announced his endorsement of you on Meet the Press, host Tom Brokaw questioned whether race played a role in Powell's decision. ${ }^{98}$ When television star Oprah Winfrey endorsed you, many assumed racial bias. ${ }^{99}$ Curiously, the racial motives of your high-profile white supporters, like conservative columnist David Brooks, went unquestioned.

A look back provides some explanation. During slavery, plantation owners intentionally separated families and enforced laws prohibiting black slaves from congregating for fear that they would plot rebellion or attempt to escape. After emancipation and even through the Civil Rights era, blacks were routinely jailed under vagrancy or loitering statutes for exercising their constitutionally guaranteed right of assembly. As columnist Michel Martin noted, this phenomenon can be seen in work environments across the nation where blacks

98 Meet the Press (NBC television broadcast, Oct. 19, 2008).
${ }_{99}$ Can I Just Tell You? (NPR radio broadcast, Oct. 20, 2008). 
say to one another: "uh, oh, there's three of us; better bust it up."100 Even your wife, Michelle (my former student at Harvard Law School), was reluctant to date you when both of you worked at the law firm of Sidley Austin, because she was concerned about the appearance of "the only two black people" at the firm dating. ${ }^{101}$ Unfortunately, as you are well aware, black politicians have the added onus of not only needing to appear completely race-neutral in their everyday lives, but also preventing the appearance of a black agenda. The subconscious fear of many (and the conscious fear of a few) whites, that blacks will band together to advance a specifically "black" agenda, is too great for black candidates to ignore and still capture a significant amount of white votes.

The "Bradley effect," named after black California gubernatorial candidate Tom Bradley who lost his election while polls showed him with a significant lead, describes the impact of what social scientists call the "social desirability bias." Put simply, when white voters are polled before elections involving a non-white candidate, they are less likely to admit their intentions not to vote for the minority candidate because of race. Because racism is socially discouraged, these voters claim they will vote for the minority candidate. When the same voters get into the voting booth, however, they cast their votes against the minority candidate, possibly based on racist beliefs. Many have used this phenomenon to explain the discrepancy between polling data and actual election data in political contests, including those of Harold Ford, Jr., Tom Bradley, and Doug Wilder.

As a result of your election, the "Bradley effect" has come under scrutiny. Indeed, pre-election support for you seemed to accurately predict your victory. The accuracy of much of the 2008 election polling, where pollsters such as Nate Silver of FiveThirtyEight.com came within fractions of a percentage point in their predictions, undermines the continued existence of the "Bradley effect." While I am optimistic that race relations have changed enough in the United States that the "Bradley effect" will be less potent than perhaps it has been in the past, I remain skeptical that race will not negatively impact some future black political candidates.

After you announced your economic stimulus plan, one that could prove to be a hallmark of your presidency, the New York Post ran a cartoon depicting you as a monkey. ${ }^{102}$ This was only the beginning. You have been called a "Nazi" and a supporter of "white slavery," and your American citizenship continues to be questioned by those who call themselves "the birthers." Some even questioned whether it was appropriate for you to speak to schoolchildren

100 Id.

101 Lisa Mundy, When Michelle Met Barack, WASH. Post MAG., Oct. 5, 2008, at W10.

102 See Brent Staples, Editorial, The Ape in American Bigotry, From Thomas Jefferson to 2009, N.Y. Times, Feb. 28, 2009, at A22. 
about the importance of education. Moreover, some of the opposition to your healthcare reform initiative and, in particular, the tactics employed by your opponents, appear unduly disrespectful, perhaps indicating a racial animus as former President Jimmy Carter has noted. ${ }^{103}$ For example, Congressman Joe Wilson's disruption of your speech to a joint session of Congress by shouting "you lie" in response to your characterization of recent immigration legislation was unprecedented. ${ }^{104}$

As I detail in my two books, In the Matter of Color $^{105}$ and Shades of Freedom, ${ }^{106}$ code words and other symbolism long utilized by bigots to signify racial inferiority are likely to return to vogue. Inevitably, some politicians will run for election on platforms that promise a return to earlier, supposedly better, times. By continuing to uphold your principles of bipartisanship and inclusion, you can show skeptical voters that they have little to lose by casting their lots with a black candidate.

Your election managed to generate the highest voter turnout this country has ever seen. Yet, barriers still exist for blacks attempting to exercise their constitutional right to vote. Gerrymandering schemes in Texas and other states could have made the black vote practically ineffectual. Reports of traffic stops, arbitrary ticketing by Florida police, and libelous telephone calls to black homes discouraging residents from voting all occurred during your presidential campaign. Felony disenfranchisement prevents thousands of blacks from voting even after they have paid their debts to society. My first law clerk (and one of my favorites), Eleanor Holmes Norton, still fights daily for universal suffrage as the non-voting representative for your new home, Washington D.C. Each day she presses her colleagues to rectify the disenfranchisement of one of the largest black urban populations in this country.

These "ghosts of Jim Crow," 107 as my nephew Michael calls them, are not worse but are certainly still as harmful as the Jim Crow laws themselvesincluding poll taxes and literacy tests-which I fought against in the early 1960 s as the President of the Philadelphia Branch of the NAACP. You will need to build some strong coalitions and fight with all your heart to correct these wrongs. Your candidacy alone proves that you are capable. Your inaugural address proves that you have the will.

${ }^{103}$ Carl Hulse, House Votes to Rebuke Lawmaker Who Shouted "You Lie" at the President, INT'L HeRALD TRIB., Sept. 17, 2009, at 4.

104 See id.

105 A. LeON HIGgInBOtHAM, JR., IN THE MATTER OF COLOR: RACE AND THE AMERICAN Legal Process: THE Colonial Period (1978).

106 A. LEON Higginbotham, JR., Shades of Freedom: Racial Poltitics AND Presumptions OF THE AMERICAN LEGAL PROCESS (1996).

107 F. Michael Higginbotham, Keynote Address, "Ghosts of Jim Crow", Washington B. Ass'n, Wash. D.C. (Oct. 19, 2006). 


\title{
IV. CONCLUSION
}

Based on what I have seen from you thus far, I am confident in your ability to unify a country scarred by the racially divisive institutions of slavery and segregation. Ridding the country of the ubiquitous "ghosts of Jim Crow" will not be easy. If you find yourself the victim of racial attacks (for example, when, during your campaign, Fox News commentator E.D. Hill referred to a "fist bump" between you and your wife as a possible terrorist gesture), ${ }^{108}$ you will again have to rise above the fray and combat them with your actions and words. The unity of your multiracial coalition may be challenged, but you must lead it and keep your coalition together with focused and principled leadership. In your 2008 campaign speech from Philadelphia, you called for a new conversation on race. Since then however, with the exception of the profiling incident involving Cambridge, Massachusetts police officer James Crowley and Harvard Professor Henry Louis Gates, you have said very little on the subject. I recognize that the economic, crime, and military problems facing the country are enormous. As a black man appointed to several powerful positions in my time, I know, first hand, the weight of office. But racial inequality, in good times and bad, has plagued America since its founding, and it will not end without new and more vigorous efforts. That is why I felt compelled to encourage you to continue the conversation on race even as you grapple with other problems. I will watch your progress from my vantage point in Heaven with pride in your accomplishments and hope for your success as the fortyfourth president of the United States.

Sincerely,

\author{
A. Leon Higginbotham, Jr. ${ }^{109}$ \\ Chief Judge (Retired) \\ United States Court of Appeals for the Third Circuit
}

\footnotetext{
108 America's Pulse (FOX News television broadcast, June 6, 2008); see also Alex Spillius, TV Presenter is Sacked for Obama "Terrorist Fist" Jibe, Dall Y TElEGRAPH (London), at 20.

109 The sentiments expressed in this letter reflect the author's best judgment as to what Judge Higginbotham might have felt and written had he been living today.
} 